\title{
Oocyte development and fecundity type of the Brazilian Snapper Lutjanus alexandrei Moura \& Lindeman, 2007 (Perciformes: Lutjanidae)
}

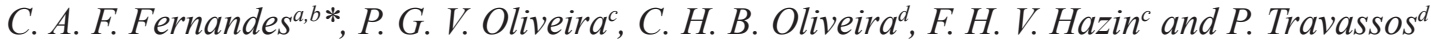

áLaboratório de Bioecologia Pesqueira, Departamento de Ciências do Mar, Universidade Federal do Piauí - UFPI, Av. São Sebastião, 2819, Reis Velloso, CEP 64202-020, Parnaíba, PI, Brazil

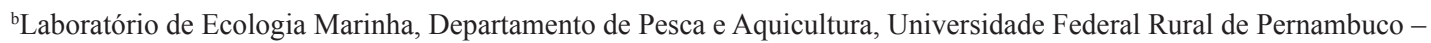
UFRPE, Rua Dom Manoel de Medeiros, s/n, Dois Irmãos, CEP 52171-900, Recife, PE, Brazil

'Laboratório de Etologia de Peixes, Departamento de Pesca e Aquicultura, Universidade Federal Rural de Pernambuco UFRPE, Rua Dom Manoel de Medeiros, s/n, Dois Irmãos, CEP 52171-900, Recife, PE, Brazil

${ }^{d}$ Laboratório de Oceanografia Pesqueira, Departamento de Pesca e Aquicultura, Universidade Federal Rural de Pernambuco - UFRPE, Rua Dom Manoel de Medeiros, s/n, Dois Irmãos, CEP 52171-900, Recife, PE, Brazil

*e-mail: cezaraff@hotmail.com

Received: August 4, 2014 - Accepted: November 5, 2014 - Distributed: February 29, 2016

(With 6 figures)

\begin{abstract}
Lutjanid species exhibit multiple spawning behaviour during an extended spawning season in warm months, asynchronous oocyte development and indeterminate fecundity. Although early studies have contributed to knowledge of the reproductive cycle of many species within the group, they have not considered aspects about the number of cortical alveoli oocyte stage throughout maturity phases along spawning season. The latter aspect is also considered very important to confirm indeterminate fecundity hypothesis. In the present study, were analyzed 154 Brazilian snapper Lutjanus alexandrei female gonads obtained from artisanal fisheries in Pernambuco State (Brazil) between October 2010 and March 2011. Were measured oocyte size frequency distribution for maturity phases (developing, spawning capable and actively spawning), and oocyte development stage (unyolked oocytes, cortical alveoli, primary, secondary and tertiary vitellogenic oocytes and hydrated oocytes), and also the oocyte stage frequency during spawning season. The frequency of cortical alveoli oocyte stage was constantly found in the spawning period ( $>37 \%)$, showing slight variation throughout maturity phases. The absence of gap in the oocyte size frequency distribution between primary and secondary oocyte growth stages during spawning season is a strong indicator of continuous oocyte recruitment from reserve stocks. In addition, co-occurrence of tertiary vitellogenic oocytes, hydrated oocytes, post-ovulatory follicles and yellow-brown bodies in the histological sections of ovaries reinforce indeterminate fecundity hypothesis.
\end{abstract}

Keywords: multiple spawning, asynchronous development, ovulation.

\section{Desenvolvimento ovocitário e tipo de fecundidade da baúna de fogo Lutjanus alexandrei Moura \& Lindeman, 2007 (Perciformes: Lutjanidae)}

\begin{abstract}
Resumo
Os lutjanídeos apresentam um comportamento de desovas parceladas ao longo de uma extensa estação reprodutiva nos meses mais quentes do ano, desenvolvimento assincrônico dos ovócitos e padrão de regulação de fecundidade indeterminado. Embora muitos estudos anteriores tenham contribuído no conhecimento do ciclo reprodutivo das espécies do grupo, não foram considerados os aspectos relacionados ao percentual dos ovócitos em estágio de cortical alveoli entre as fases de maturidade sexual durante a estação reprodutiva. Este último aspecto, considerado importante para confirmação da hipótese de fecundidade do tipo indeterminada. Para isso, no presente trabalho foram analisadas 154 gônadas de fêmeas da baúna de fogo Lutjanus alexandrei obtidas da pesca artesanal em Pernambuco entre o período de outubro de 2010 a março de 2011. Foram mensurados os diâmetros dos ovócitos nas fases de maturidade sexual (desenvolvimento, capaz de desovar e ativamente desovando), e para todos os estágios ovocitários (ovócitos pre-vitelogênicos, cortical alveolar, vitelogênese primária, secundária, terciária e ovócitos hidratados), e avaliada a frequência de ocorrência ao longo do período de desova. O percentual de ovócitos em estágio cortical alveoli permaneceu constante durante o período de reprodutivo (>37\%), apresentando pouca variação entre as fases de maturidade sexual. A ausência de um intervalo na frequência de diâmetro dos ovócitos em crescimento primário e secundário entre todas as fases de maturidade sexual é um forte indicador de recrutamento contínuo de ovócitos do estoque de reserva. Além disso, a presença conjunta de ovócitos em vitelogênese terciária, ovócitos hidratados, folículos pós-ovulatórios e corpos amarelados nos cortes histológicos reforçam a hipótese de fecundidade do tipo indeterminada.
\end{abstract}

Palavras-chave: múltipla desova, desenvolvimento assincrônico, ovulação. 


\section{Introduction}

The snappers, family Lutjanidae, are reef and mangrove fish species, commonly known as red fishes. Occurring in tropical and subtropical areas of all oceans, they constitute an important fishery resource worldwide (Allen, 1985; Heyman et al., 2005). The snappers are long-lived species, with medium to large size, inhabiting mainly shallow waters up to $450 \mathrm{~m}$ in depth, and feeding basically on crustaceans and mollusks (Nelson, 1984; Newman et al., 1996; Claro and Lindeman 2004).

The Brazilian snapper Lujanus alexandrei (Moura and Lindeman, 2007) is a recently described species of Lutjanidae, a family which includes thirteen species with confirmed occurrence in Brazil (Floeter et al., 2003; Freire and Carvalho-Filho, 2009). Some interesting features of this particular species are its endemic nature, a trait that had never been reported before for any other snapper in Brazil, and its limited area of occurrence along the coastline between the state of Maranhão and Bahia (Moura and Lindeman, 2007). Certainly because of the recent description, very little information is available on the Brazilian snapper particularly on its reproductive biology.

Like most of fish species in the family Lutjanidae, the Brazilian snapper is a multiple batch spawner with asynchronous oocyte development and indeterminate fecundity regulation (Bannerot et al., 1987; Ferreira et al., 2004; Evans et al., 2007; Brulé et al., 2010; Freitas et al., 2011; Fernandes et al., 2012). In this case, several batches of eggs are produced during spawning season, gonads histological sections exhibit continuous oocyte recruitment from reserve stocks, and fecundity estimation is obtained per batch (Hunter et al., 1985, Brown-Peterson et al., 2011). The species exhibits an extended spawning season between October and March, with a peak spawning in February (Fernandes et al., 2012). This observation is derived from previous studies about the reproductive strategy of the lutjanid species based on histological criteria (e.g. all oocyte stage in ovary occurring simultaneously for all maturity phases, presence of hydrated oocytes and post ovulatory follicles, and continuous oocyte diameter distribution in actively spawning females) which indicate indirectly multiple batch spawning and indeterminate fecundity (Grande et al., 2013).

Consequently, studies on the reproductive strategies of the snappers have to be complemented to confirm indeterminate fecundity regulation. The stage-specific and seasonal variation of oocyte size frequency distribution, seasonal variation in the percentage of different oocyte stages in individuals in spawning capable phase, and seasonal variation in the mean diameter of oocytes in the tertiary vitellogenesis stage in individual in spawning capable phase through spawning season are required (West, 1990; Hunter and Macewicz, 1985c; Murua et al., 2003; Brown-Peterson et al., 2011; Lowerre-Barbieri et al., 2011; Grande et al., 2013).

The aim of this paper was to describe the oocyte development and fecundity type of the Brazilian snapper to help understanding the life cycle and spawning patterns of the species, by means of histological analysis of female gonads, based on oocyte growth and recruitment style criteria to test indeterminate fecundity hypothesis as previous mentioned.

\section{Material and Methods}

A total of 157 female specimens were obtained from landings of artisanal fishing boats, operating with traps, in Itamaracá Island, on the northern coast of Pernambuco State, Brazil (Figure 1), from October 2010 to March 2011. About 19 fish, on average (ranging from 15 to 57), were examined per month. The relatively short sampling period was purposely selected to cover the spawning season for this species proposed by Fernandes et al. (2012).

To verify maturity phases, a small section of the gonads of all specimens sampled were dehydrated (alcohol), cleared (xylene), embedded in paraffin, sectioned in microtome $(5 \mu \mathrm{m})$ and then stained (hematoxylin-eosin) (Mackie and Lewis, 2001). Microscopic characterization of gonad development was obtained from the grading key for sexual maturity phases for the Brazilian snapper proposed by Fernandes et al. (2012) and adapted from Brown-Peterson et al. (2011), according to the most advanced oocyte stage present in the gonad (West 1990).

The oocyte development was analyzed in females which were developing (in the beginning of the spawning season), spawning capable and actively spawning (from the middle to the peak of spawning months), following the histological staging adapted by Brown-Peterson et al. (2011). The maturity phases were classified as follow: (1) Developing: abundance of previtellogenic oocytes, cortical alveoli stage, along with some early advanced yolked oocytes; (2) Spawning capable: high abundance of

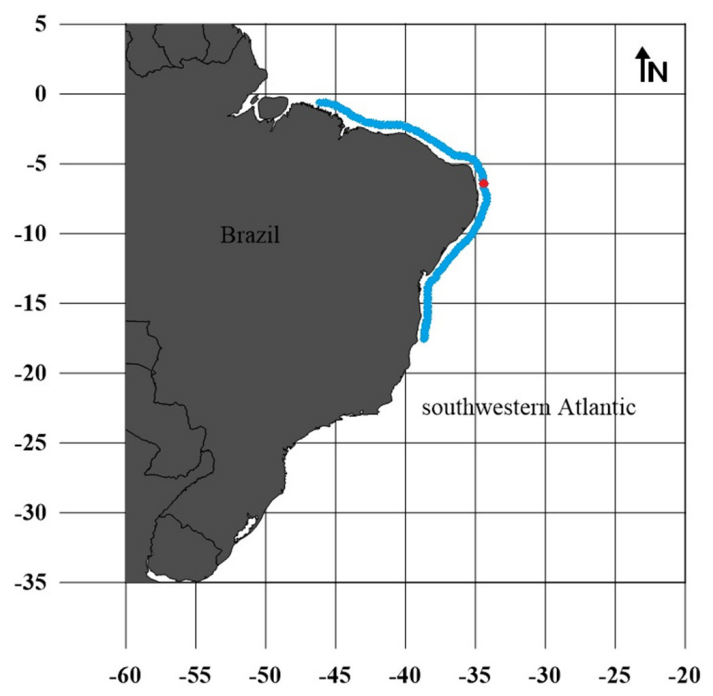

Figure 1. Distribution area of the Brazilian Snapper Lutjanus alexandrei in Brazil (blue line), and the survey area (red point). 
advanced yolked oocytes and no hydrated oocytes present; and (3) Actively spawning: many hydrated oocytes, all oocyte growth stages present and rare post-ovulatory follicles.

To describe oocyte development, five oocyte stages were used, as suggested by Wallace and Selman (1981), Hunter and Macewicz (1985b), and Brown-Peterson et al. (2011), as follow: (I) Unyolked, (II) Primary growth and cortical alveoli, (III) Partially yolked (primary vitellogenesis Vtg1 and secondary vitellogenesis Vtg2), (IV) Advanced yolked (tertiary vitellogenesis Vtg3), and (V) Hydrated oocytes (germinal vesicle migration GVM, germinal vesicle breakdown GVBD, and hydrated oocyte HO) (see Table 1).

In order to assess the oocyte size-frequency distribution of oocyte diameter, 100 oocytes were randomly measured for each specimen from all maturity phases sampled, using the methodology adapted from West (1990), Hunter et al. (1985) and Grande et al. (2013). The oocyte diameter was measured as the average of the major and minor axes, and the limit for each stage was identified as the limits of confidence intervals which did not overlap the mean value to segregate the oocyte stages. The prevalence of each oocyte stage was obtained between developing and actively spawning phase. The mean diameter of the most advanced vitellogenic stage $(\mathrm{Vtg} 3)$ from the largest 100 oocytes was also measured for assessment of seasonal variation. The measurements were made by stereomicroscope with the software Image Tools 3.0. The arithmetic means and standard deviations were calculated for all oocyte growth stages and all maturity phases. The normality of oocyte size frequency distribution for maturity phases was tested by Shapiro-Wilk $(P<0.05)$. In non normal distribution differences in oocyte diameter distribution between maturity phase and stages were tested by non parametric Kruskal-Wallis or Mann-Whitney $(P<0.05)$ test to verify statistically significant differences (Zar, 1999).

\section{Results}

\subsection{Oocyte development stages and oocyte diameter size distribution}

Of the 157 females, $12.7 \%(\mathrm{n}=20)$ were in developing phase, $39.5 \%$ were spawning capable $(n=62)$ and $47.8 \%$ were actively spawning $(n=75)$. The histological section of ovaries showed evidence of a multiple spawning, by the simultaneous presence of all types of oocytes growth stages in the three reproductive phases evaluated, except for hydrated oocytes which were exclusively found in the actively spawning phases.

During vitellogenesis the oocytes develop from primary growth stage to cortical alveolar (CA) which is the early stage of the secondary growth (Figure 2a-b), to progress throughout primary Vtg1 and secondary Vtg2 (partially yolked) (Figure 2c), and tertiary vitellogenesis stages Vtg3 (advanced yolked) (Figure 2d). The oocyte maturation begins with germinal vesicle migration (GVM, early hydration), going to germinal vesicle breakdown (GVBD, middle hydration) and hydrated oocyte stage (HO, final hydration) when it is previous to spawning (Figure 2e-f). Before ovulation, the oocytes are released from their follicles, and post ovulatory follicles (POF) are commonly observed in ovaries. The simultaneous presence of advanced yolked oocytes (Vtg3), hydrated oocyte (HO), post ovulatory follicles (POF), and yellow brown bodies $(\mathrm{Yb})$ are indicators of multiple spawning behaviors.

Fishes which were in the development phase exhibited previtellogenic oocytes (unyolked stages), cortical alveolar, primary and secondary vitellogenesis stages (Vtg1 and $\mathrm{Vtg} 2)$, and sometimes tertiary vitellogenesis stages (Vtg3) in ovaries as observed occasionally. The oocyte diameter in the development phase varied between 26.16 and $635.92 \mu \mathrm{m}$ (mean $291 \pm 187.05$ S.D.), and there was no gap between primary growth to secondary growth stage, indicating continuous oocyte diameter distribution (Figure 3a).

Table 1. Description of oocyte development for the Brazilian snapper Lutjanus alexandrei.

\begin{tabular}{|c|c|c|c|}
\hline Oocyte growth phase & Morphological characteristic & Size range & Mean \pm SD \\
\hline Unyolked & $\begin{array}{l}\text { All oocytes without yolk. Majority } \\
\text { of oocytes are oogonium nests, } \\
\text { and large oocytes have a large } \\
\text { nucleus with a narrow homogenous } \\
\text { cytoplasm. }\end{array}$ & 16.16 to $69.53 \mu \mathrm{m}$ & $46.18 \pm 13.13$ \\
\hline $\begin{array}{l}\text { Primary growth and cortical } \\
\text { alveoli } \\
\text { (CA) }\end{array}$ & $\begin{array}{l}\text { Oval nucleus containing several } \\
\text { nucleoli and surrounded by a } \\
\text { granular perinuclear zone. Small } \\
\text { vesicles in the periphery of } \\
\text { cytoplasm. Cortical alveoli stage } \\
\text { begins. }\end{array}$ & 100.2 to $205 \mu \mathrm{m}$ & $156.22 \pm 31.76$ \\
\hline $\begin{array}{l}\text { Partially yolked } \\
\text { (Vtg1 and Vtg2) }\end{array}$ & $\begin{array}{l}\text { Early stage of yolk deposition up to } \\
\text { yolk granules or spherules. }\end{array}$ & 178.7 to $329.02 \mu \mathrm{m}$ & $268.33 \pm 37.14$ \\
\hline $\begin{array}{l}\text { Advanced yolked } \\
(\text { Vtg3) }\end{array}$ & $\begin{array}{l}\text { Yolk spherules and large globules } \\
\text { up to germinal vesicle breakdown. }\end{array}$ & 411.07 to $635.92 \mu \mathrm{m}$ & $450.37 \pm 45.43$ \\
\hline $\begin{array}{l}\text { Hydrated } \\
\text { (GVM, GVBD, and HO) }\end{array}$ & $\begin{array}{l}\text { Nucleus has migrated to animal } \\
\text { pole. Globules fuse to form yolk } \\
\text { plates. }\end{array}$ & 742.65 to $994.56 \mu \mathrm{m}$ & $767.43 \pm 141.33$ \\
\hline
\end{tabular}


The mean percentage of cortical alveolar stage was 53\%, Vtg1 (33\%) and Vtg2 (14\%) (Figure 4a).

After reaching maturity, a random mixture of all oocytes growth stages (PG, CA, Vtg1, Vtg2 and Vtg3) was observed in ovaries, except for hydrated oocytes. The oocyte diameter size distribution varied between 28.13 and $742.65 \mu \mathrm{m}$ (mean $446.13 \pm 74.31$ S.D.) (Figure 3b). The oocytes in cortical alveolar stage decreased it prevalence in ovaries $(\mathrm{CA}=38 \%)$ for females in the spawning capable phase, and Vtg1 and Vtg2 was $32 \%$ and $17 \%$ respectively (Figure $4 b$ ). The tertiary
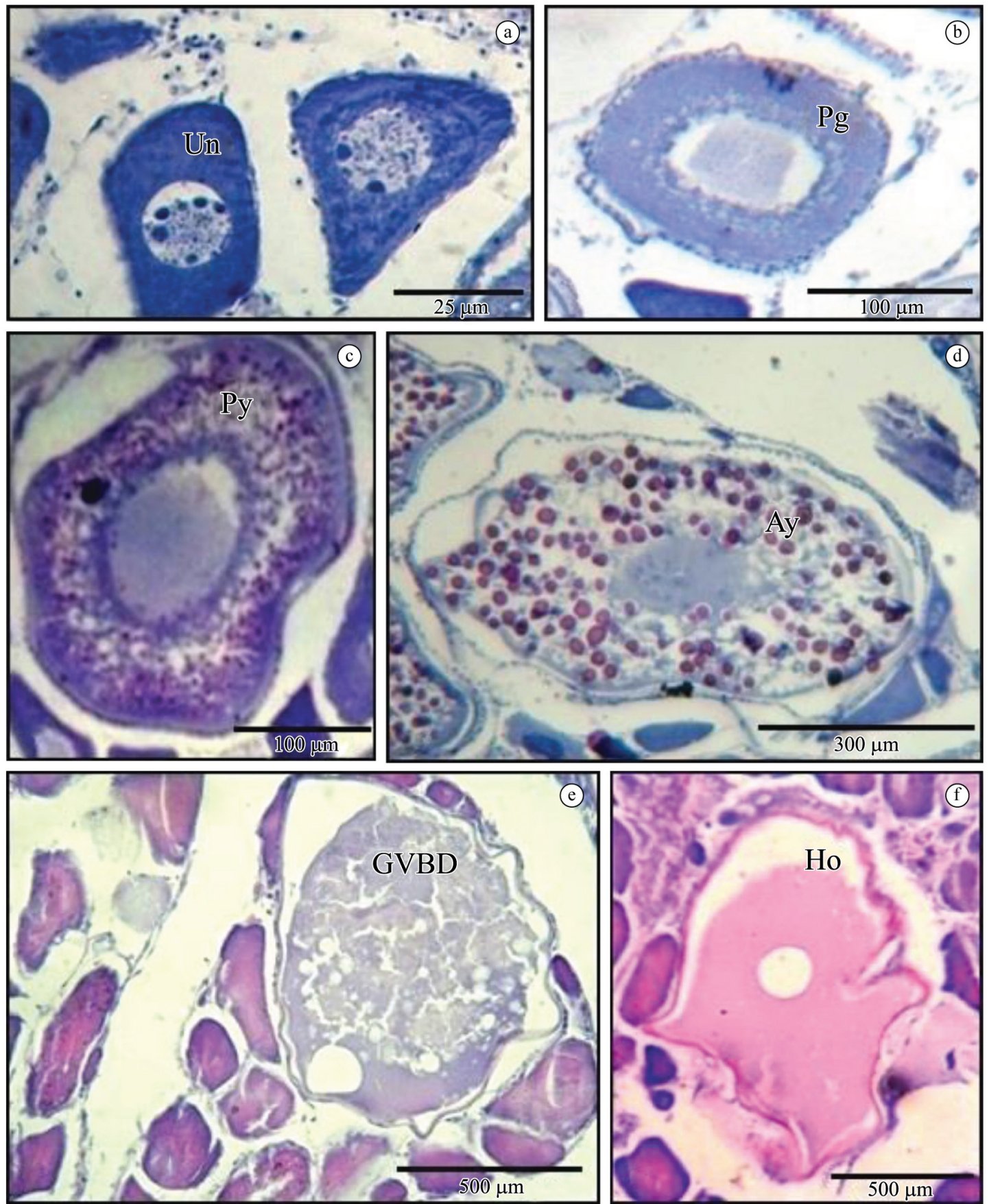

Figure 2. Histological section of the ovaries showing the types of oocyte growth stages for the Brazilian snapper Lutjanus alexandrei. (a) Unyolked oocyte with a small nucleus surrounded by nest of germ cells nest. (b) Primary growth oocyte in the early vitellogenesis stage (PG and CA) showing initial enlargement of the nuclus. (c) Partially yolked oocyte in the beginning of spherules stage (Vtg1 and Vtg2) exibitng lipid vacuoles. And (d) Advanced yolked oocyte in the spherules and globules stage (Vtg3) showing yolk platelets. (e) Germinal vesicle breakdown in the time of nucleus migration (GVM and GVBD). (f) Hydrated oocyte in the late hydration stage during the ovulation process showing hydrated cytoplasm (HO). 


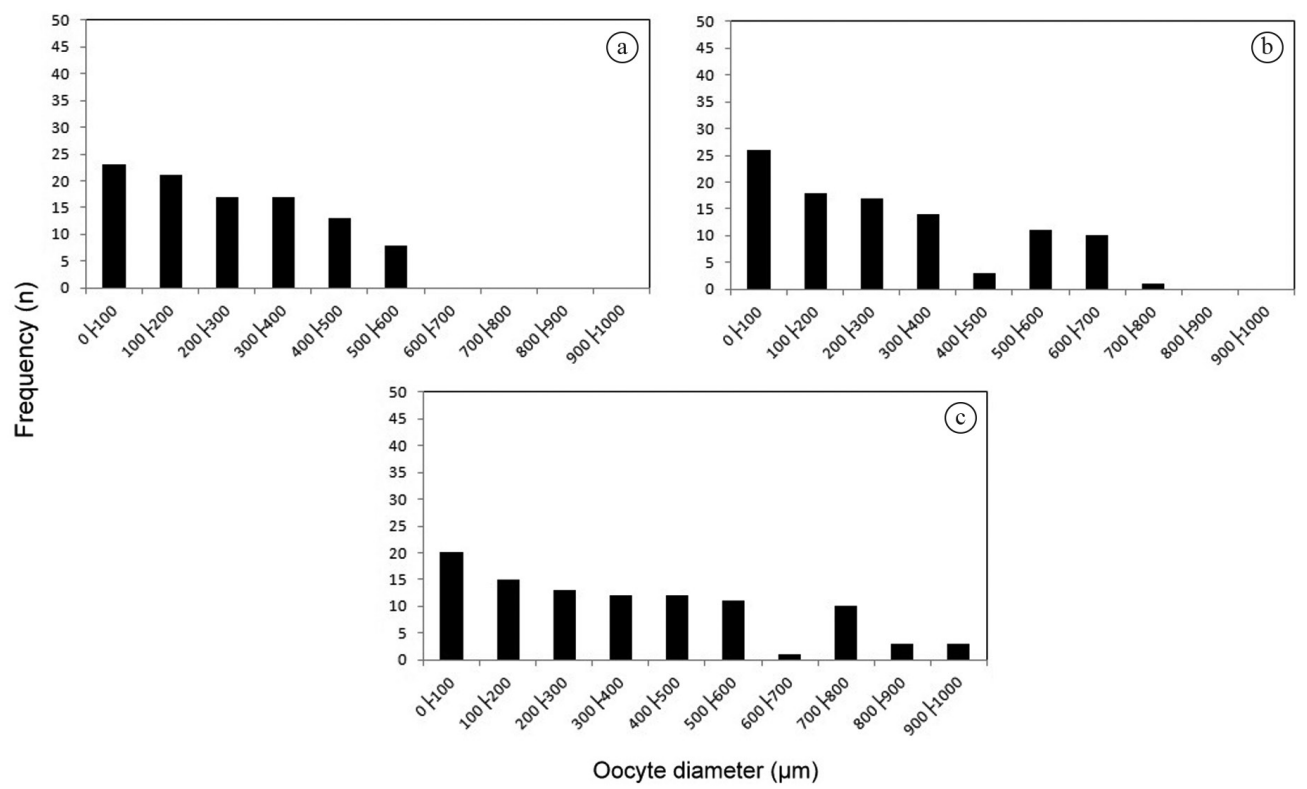

Figure 3. Frequency distribution of Lutjanus alexandrei oocytes (whole mount) for each $100 \mu \mathrm{m}$ diameter size at different maturity phases: (a) developing phase $(n=20)$; (b) spawning capable phase $(n=62)$; and (c) actively spawning phase $(n=75)$.

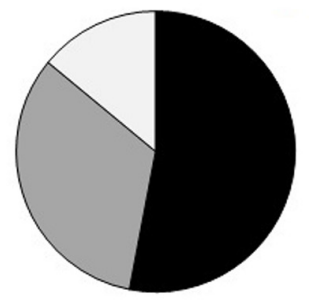

(a)
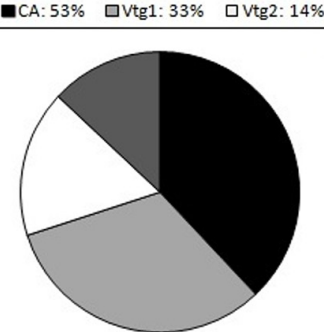

口CA: $38 \% \quad \square V \operatorname{tg} 1: 32 \% \quad \square V \operatorname{tg} 2: 17 \% \quad \square \operatorname{Vtg} 3: 13 \%$

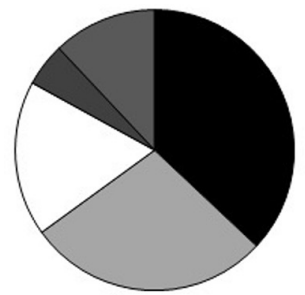

(b)

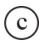

aCA: $37 \%$ पVtg1: $28 \%$ aVtg2: $18 \%$ aVtg3: $5 \%$ q GVM/GVBD/HO : $12 \%$

Figure 4. Average percentage of oocyte stages in females of Lutjanus alexandrei at different maturity phases: (a) developing phase $(\mathrm{n}=20)$ with $\mathrm{Vtg} 2$ as the most advanced oocyte stage; (b) spawning capable $(n=62)$ with $\operatorname{Vtg} 3$ as the most advanced oocyte stage; and (c) actively spawning $(\mathrm{n}=75)$ with $\mathrm{HO}$ as the most advanced oocyte stage. vitellogenesis oocyte (Vtg3) was the most advanced oocyte stage in this reproductive phase, with prevalence of $13 \%$. The distribution of oocyte diameter size was significantly different between developing and spawning capable phases (Mann-Whitney test; $\mathrm{U}=218.0 ; P=0.0001$ ).

Previous to spawning, fishes exhibited ovaries full of oocytes in maturation stages (GVM, GVBD and HO), and also all primary and secondary growth oocytes stages (PG, CA, PG, CA, Vtg1, Vtg2, Vtg3). The oocyte diameter varied between 26.95 and $994.56 \mu \mathrm{m}$ (mean $577.42 \pm 185.49$ S.D.) (Figure $3 \mathrm{c}$ ). In the maturation stage (ovulation), a small gap will separate the standing stock and advanced yolked oocytes (Vtg3) from hydrated oocytes which increases in diameter previous of the spawning, and the remaining oocytes in vitellogenesis will be spawned in the subsequent batch. The oocyte from the reserve stock will be recruited, and increase in size to be spawned in multiple batches. The prevalence of cortical alveolar stage was 37\%, Vtg1 (28\%), Vtg2 (18\%), Vtg3 (5\%), and GVM, GVBD and HO $(12 \%)$ (Figure $4 c)$. The distributions of oocyte diameter size was not significantly different between spawning capable and actively spawning reproductive phases (Mann-Whitney test; $\mathrm{U}=408.0 ; P=0.324$ ).

The monthly variation of oocyte stages and oocyte diameter did not vary for any reproductive phase (development, spawning capable and actively spawning) during the spawning season (from October to March), with all oocytes stages present in ovaries exhibiting continuous oocyte recruitment. The oocyte stage diameter range did not vary for any months individually and between reproductive phase, showing constantly prevalence of primary growth oocytes, cortical alveolar stages and secondary growth stages for development and spawning capable phase, and hydrated oocyte for actively spawning reproductive phase (Figure 5). 
3.2. Seasonal variation in the relative number of oocytes stage in females in the spawning capable phase

The relative frequency of tertiary vitellogenesis oocytes (Vtg3) did not vary significantly, and Vtg3 was the most advanced oocyte stage in ovaries from females in the spawning capable reproductive phase (Figure 6). The percentage of tertiary vitellogenesis (Vtg3) oocytes during spawning season was $10 \%$ and $13 \%$ (Oct and Nov), $17 \%$ and $13 \%$ (Dec and Jan), and $10 \%$ and $11 \%$ (Feb and Mar). The percentage of cortical alveolar stage (CA) was

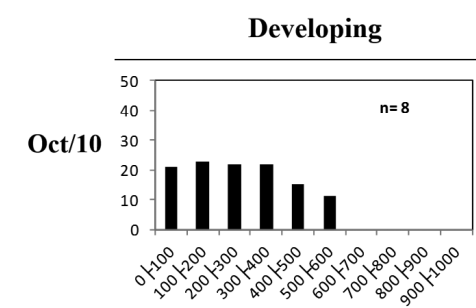

Spawning capable

Actively spawning
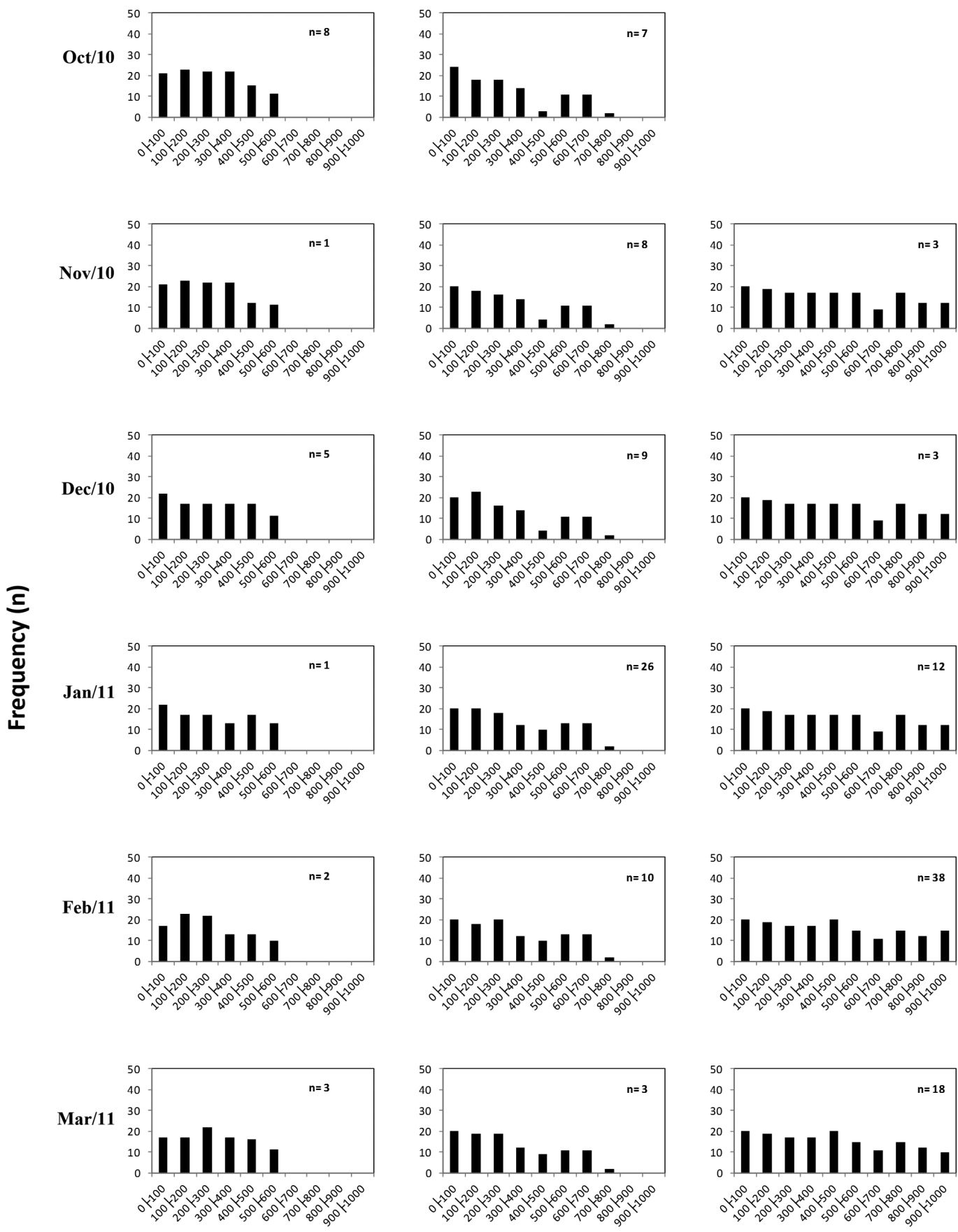

\section{Oocyte diameter $(\mu \mathrm{m})$}

Figure 5. Monthly change in the frequency distribution of oocytes (whole mounts) by $100 \mu \mathrm{m}$ diameter size classes in different maturity phases of Lutjanus alexandrei. 


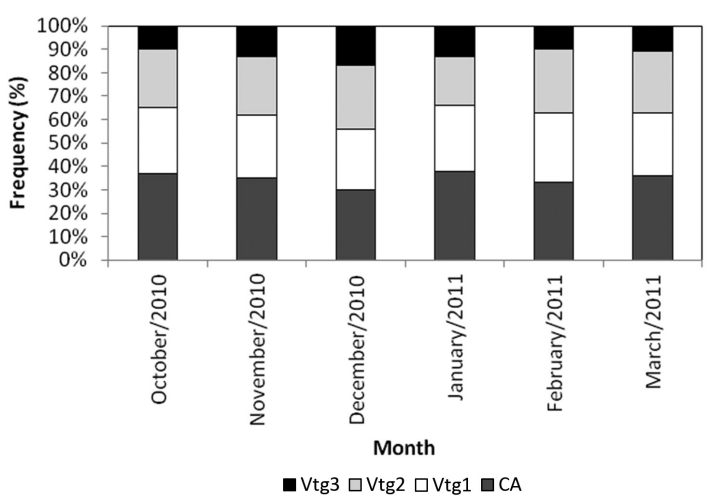

Figure 6. Seasonal variation in the percentage of oocytes stages in spawning capable phase of Lutjanus alexandrei with Vtg3 as the most advanced oocyte stage $(n=62)$.

$37 \%$ and $35 \%$ in the early of the spawning season (October and November), $30 \%$ and $38 \%$ in the middle (December and January), and $36 \%$ in the peak spawning months (February and March) (Figure 6). This is an indicative for continuous oocyte recruitment during the spawning season.

\subsection{Seasonal variation in the mean diameter of oocyte in the most advanced vitellogenic stage in females in the spawning capable reproductive phase}

In this reproductive phase, the diameter of the most advanced oocyte stage in the ovaries ( Vtg3) varied with a short range of $54.67 \mu \mathrm{m}$ between months during spawning season (Figure 6). There was no statistically significant difference in the mean diameter between October to March (Kruskal-Wallis test; $\mathrm{K}=1.071 ; P=0.985$ ).

\section{Discussion}

Based on histological sections of ovaries and the oocyte size frequency distribution were able to classify the ovarian development organization of the Brazilian snapper as asynchronous, and the reproductive style as indeterminate fecundity spawner species. The presence of all types of oocyte growth stages in actively spawning females observed in this study is an indication of a multiple spawning behavior (Hunter et al., 1985; Hunter and Macewicz, 1985a). This is also a feature that has been reported for many snapper species in Brazil, such as mutton snapper Lutjanus analis (Cuvier, 1828), dog snapper L. jocu (Bloch \& Schneider, 1801), lane snapper L. synagris (Linnaeus, 1758), silk snapper L. vivanus (Cuvier, 1828), yellowtail Ocyurus chrysurus (Bloch, 1791) and vermilion snapper Rhomboplites aurorubens (Cuvier, 1829) (Ferreira et al., 2004, Freitas et al., 2011).

The Brazilian snapper, like many other indeterminate spawners, produces several clutches of hydrated oocytes to be released in portions during the spawning season. This was clearly observed due to the presence of a gap in the oocyte size frequency distribution between hydrated oocytes and advanced yolked oocytes in the actively spawning phase (Lowerre-Barbieri et al., 2011; Brown-
Peterson et al., 2011). Multiple spawning is a condition reported for many other coral reef fish species, such as Nassau grouper Epinephelus striatus (Bloch, 1792) (Colin, 1992), inshore coral trout Plectropomus maculatus (Bloch, 1790) (Ferreira, 1993), gag Mycteroperca microleps (Goode \& Bean, 1879) (Brulé et al., 2003), coney Cephalopholis fulva (Linnaeus, 1758) (Trott, 2006), white grunt Haemulon plumieri (Lacépède, 1801) (Palazón-Fernandéz, 2007; Shinozaki-Mendes, 2013a, b), and mutton hamlet Alphestes afer (Bloch, 1793) (Marques and Ferreira, 2011). Overall, coral reef fish species present a variety of complex spawning systems, but among them two major groups are generally observed: (1) demersal spawners, showing a synchrounous oocyte development and total spawning, represented mainly by species of the families Gobiidae, Blenniidae and Pomacentridae; and (2) pelagic spawners, exhibiting asynchronous oocyte development and spawning in portions, represented by families such as Lutjanidae, Haemulidae, Carangidae, Mullidae, and Gerreidae (Rong-Quen, 2000; Petersen and Warner, 2002).

For the majority of fish species, two mainly reproductive styles are commonly observed. The determinate fecundity spawners are fishes that produce several oocytes synchronously to be spawned in a short period. The standing stock is separated from advanced yolked oocytes, with a gap observed in the oocyte size frequency distribution. In this case oocytes are not recruited from reserve stock during spawning season. And the indeterminate fecundity spawner recruit oocytes from standing stock permanently during an extended spawning season, and spawned in batches of oocytes (West, 1990; Hunter et al., 1985; Hunter and Macewicz, 1985a, b; Murua et al., 2003). The Brazilian snapper exhibited continuous oocyte recruitment due to the presence of all oocyte size stages in ovaries from females in development, spawning capable and actively spawning phases during spawning season, and no change in the proportion of all oocyte stages between all reproductive phases in each month individually.

Fish reallocate energy resources provided from feeding season to the liver, increasing lipid and protein levels for maintenance of oocyte growth during vitellogenesis (Wallace and Selman, 1981). Gonad maturation begins with initial vitellogenesis, after some clutches of previtellogenic oocytes starts to grow and to increase in diameter (Hunter et al., 1985). In the asynchronous oocyte development a group of most advanced yolked oocyte stage is mainly observed, although preserving constant production of oocytes in many different growth stages in ovaries (West 1990). This was observed for the Brazilian snapper, especially in the case of spawning capable females which exhibited a prevalence of cortical alveolar stage (CA) of around $35 \%$ for all months during spawning season. Such feature indicates oocyte production during vitellogenesis due to the progress from primary to secondary growth stage (Murua et al., 2003).

Batch spawning is commonly found in a variety of marine tropical pelagic fishes which permits fish to increase fecundity as well as the chances for spawning success and survival of eggs and larvae (Hunter et al., 1985; Hunter and 
Macewicz, 1985a, b; Sadovy, 1996; Arocha and Bárrios, 2009). Large size snapper species, such as the mutton snapper $L$. analis, performs mass spawning aggregations and can persist for many days in the spawning grounds (Burton et al., 2005; Kojis and Quinn, 2011). In this case, the species produces several clutches of hydrated oocytes that will be released overnight, while during the following day, advanced yolked oocytes initiate their maturation process to be spawned on the next night (Suzuki and Hioki, 1979; Hunter and Macewicz, 1985b; Hamamoto et al., 1992).

Grimes (1987) reported extending protracted spawning season, over several months, for many lutjanids species. In general, snappers present a clear seasonal spawning (Kritzer, 2004; Grandcourt et al., 2006), with an extended period of discontinuity (Kaunda-Arara and Ntiba, 1997; Rojas, 1997; Teixeira et al., 2010). Synchronous oocyte development, such as in the determinate fecundity spawner species, followed by an asynchrony during ovulation and batch spawning events were reported for some snappers species in Cuba which inhabit shallow waters, e.g. Lutjanus synagris, L. griseus (Linnaeus, 1758) and L. apodus (Walbaum, 1792), presumably because of short marked summer season in this region (Gárcia-Cagide et al., 1994, 2001).

The Brazilian snapper exhibited asynchronous oocyte development in ovaries and indeterminate fecundity, releasing eggs in multiple occasions during the breeding season, like many other species of the family Lutjanidae. The spawning frequency and atresia rates, which constitute important information to identify the timing of spawning, should be further investigated, to provide more accurate fecundity estimates. The number of atretic oocytes (e.g. oocytes not released during spawning season) is very important for the potential fecundity estimations, considering losses of oocytes not spawned year-round (Hunter and Macewicz, 1985c).

\section{Conclusions}

Based on the criteria investigated in this study, the Brazilian snapper showed asynchronous oocyte development and indeterminate fecundity reproductive style. Ovaries from females in different reproductive phase (development, spawning capable and actively spawning) exhibited oocytes in different size and development stages, continuous recruitment of oocytes from reserve stock, no variation of the percentage of oocytes stages between maturity phases and during spawning season, and no formation of a gap in the oocyte size frequency distribution, except for actively spawning females which exhibited a gap between hydrated oocyte and standing stock.

\section{Acknowledgements}

The authors would like to acknowledge the Coordenação de Aperfeiçoamento de Pessoal de Nível Superior (CAPES) for providing a scholarship and the Conselho Nacional de Desenvolvimento Científico e Tecnológico $(\mathrm{CNPq})$ for the Research Grant.

\section{References}

ALLEN, G.R., 1985. FAO species catalogue. Rome: FAO. FAO Fisheries Synopsis, vol. 6, no. 125.

AROCHA, F. and BÁRRIOS, A., 2009. Sex ratios, spawning seasonality, sexual maturity, and fecundity of white marlin (Tetrapturus albidus) from the western central Atlantic. Fisheries Research, vol. 95, no. 1, pp. 98-111. http://dx.doi.org/10.1016/j. fishres.2008.08.010.

BANNEROT, S., FOX, W.W. and POWERS, J.E., 1987, Reproductive strategies and the management of snappers and groupers in the Gulf of Mexico and Caribbean. In: J.J. POLOVINA and S. RALSTON, eds. Tropical snappers and groupers: biology and fisheries management. Boulder: Westview Press, pp. 561-603.

BROWN-PETERSON, N., WYANSKI, D.M., SABORIDO-REY, F., MACEWICZ, B.J. and LOWERRE-BARBIERI, S.K., 2011. A standardized terminology for describing reproductive development in fishes. Marine and Coastal Fisheries, vol. 3, no. 1, pp. 52-70. http://dx.doi.org/10.1080/19425120.2011.555724.

BRULÉ, T., DÉNIEL, C., COLÁS-MARRUFO, T. and RENÁN, X., 2003. Reproductive biology of gag in the southern Gulf of Mexico. Journal of Fish Biology, vol. 63, no. 6, pp. 1505-1520. http://dx.doi.org/10.1111/j.1095-8649.2003.00263.x.

BRULÉ, T.C., COLÁS-MARRUFO, D.T., PÉREZ-DIÁZ, E. and SÁMANO-ZAPATA, R.C., 2010. Red snapper reproductive biology in the Southern Gulf of Mexico. Transactions of the American Fisheries Society, vol. 139, no. 4, pp. 957-968. http:// dx.doi.org/10.1577/T09-125.1.

BURTON, M.L., BRENNAN, K.J., MUÑOZ, R.C. and PARKER JUNIOR, R.O., 2005. Preliminary evidence of increased spawning aggregations of mutton snapper (Lutjanus analis) at Riley's Hump two years after establishment of the Tortugas South Ecological Reserve. Fish Bulletin, vol. 103, pp. 404-410.

CLARO, R. and LINDEMAN, K.C., 2004, Biología y manejo de los pargos (Lutjanidae) en el Atlántico occidental. La Habana: Instituto de Oceanología/Instituto de Geofisíca y Astronomía/ Ministerio de Ciencia, Tecnología y Medio Ambiente. 472 p.

COLIN, P.L., 1992. Reproduction of the Nassau grouper, Epinephelus striatus (Pisces: Serranidae) and its relationship to environmental conditions. Environmental Biology of Fishes, vol. 34, no. 4, pp. 357-377. http://dx.doi.org/10.1007/BF00004740.

EVANS, R.D., RUSS, G.R. and KRITZER, J.P., 2007. Batch fecundity of Lutjanus carponotatus (Lutjanidae) and implications of no-take marine reserves on Great Barrier Reef, Australia. Coral Reefs, vol. 27, no. 1, pp. 179-189. http://dx.doi.org/10.1007/ s00338-007-0309-8.

FERNANDES, C.A.F., OLIVEIRA, P.G.V., TRAVASSOS, P.E.P. and HAZIN, F.H.V., 2012. Reproduction of the Brazilian snapper, Lutjanus alexandrei (Moura \& Lindeman, 2007) (Perciformes: Lutjanidae), off the northern coast of Pernambuco, Brazil. Neotropical Ichthyology, vol. 10, no. 3, pp. 587-592. http://dx.doi. org/10.1590/S1679-62252012005000022.

FERREIRA, B.P., 1993. Reproduction of the inshore coral trout Plectropomus maculates (Perciformes: Serranidae) from the Central Great Barrier Reef, Australia. Journal of Fish Biology, vol. 42, pp. 831-844. http://dx.doi.org/10.1111/j.1095-8649.1993.tb0039.

FERREIRA, B.P., REZENDE, S.M., TEIXEIRA, S.F., FREDOU, T. and FERREIRA, Y.D., 2004, Espécies alvo: demersais. In: R.P. LESSA, M.F. NÓBREGA and J.L. BEZERRA JUNIOR, eds. 
Dinâmica de populações e avaliação dos estoques dos recursos pesqueiros da região Nordeste. Recife: Ministério de Meio Ambiente. 246 p. Programa de Avaliação Sustentável dos Recursos Vivos da Zona Econômica Exclusiva do Brasil - REVIZEE.

FLOETER, S.R., GASPARINI, J.L., ROCHA, L.A., FERREIRA, C.E.L., RANGEL, C.A. and FEITOZA, B.M., 2003 [viewed 23 June 2012]. Brazilian reef fish fauna: checklist and remarks [online]. Brazilian Reef Fish Project. Available from: www. brazilianreeffish.cjb.net

FREIRE, K.M.F. and CARVALHO-FILHO, A., 2009. Richness of common names of Brazilian reef fishes. Pan-American Journal of Aquatic Sciences, vol. 4, no. 2, pp. 96-145.

FREITAS, M.O., MOURA, R.L., FRANCINI-FILHO, R.B. and MINTE-VERA, C.V., 2011. Spawning patterns of commercially important reef fish (Lutjanidae and Serranidae) in the tropical western South Atlantic. Scientia Marina, vol. 75, no. 1, pp. 135146. http://dx.doi.org/10.3989/scimar.2011.75n1135.

GARCÍA-CAGIDE, A., CLARO, R. and KOSHELEV, B.V., 1994, Reproducción. In: R. CLARO, ed. Ecología de los peces marinos de Cuba. México: Instituto de Oceanología/Academia de Ciencias de Cuba y Centro de investigaciones de Quintana Roo, pp. 187-262.

GARCÍA-CAGIDE, A., CLARO, R. and KOSHELEV, B.V., 2001, Reproductive patterns of fishes of the Cuban shelf. In: R. CLARO, K.C. LINDEMAN and L.R. PARENTI, eds. Ecology of the marine fishes of Cuba. London: Smithsonian Institution Press, pp. 73-114.

GRANDCOURT, E.M., ABDESSALAAM, T.Z.A. and FRANCIS, F., 2006. Age, growth, mortality and reproduction of the blackspot snapper, Lutjanus fulviflamma (Forsskal, 1775), in the Southern Arabian Gulf. Fisheries Research, vol. 78, no. 2-3, pp. 203-210. http://dx.doi.org/10.1016/j.fishres.2005.11.021.

GRANDE, M., MURUA, H., ZUDAIRE, I. and KORTA, M., 2013. Oocyte devlopment and fecundity type of the skipjack, Katsuwonus pelamis, in the Western Indian Ocean. Journal of Sea Research, vol. 73, no. 1, pp. 117-125. http://dx.doi.org/10.1016/j. seares.2012.06.008.

GRIMES, C., 1987, Reproductive biology of the Lutjanidae: a review. In: J.J. POLOVINA and S. RALSTON, eds. Tropical Snappers and Groupers: biology and fisheries management. Colorado: Westview Press, pp. 239-295.

HAMAMOTO, S., KAMUGAI, S., NOSAKA, K., MANABE, S., KASUGA, A. and IWATSUKI, Y., 1992. Reproductive behavior, eggs and larvae of a lutjanid fish, Lutjanus stellatus, observed in aquarium. Japanese Journal of Ichthyology, vol. 39, pp. 219-227. http://dx.doi.org/10.1007/BF02905479.

HEYMAN, W.D., KJERFVE, B., GRAHAM, R.T., RHODES, K.L. and GARBUTT, L., 2005. Spawning aggregations of Lutjanus cyanopterus (Cuvier) on the Belize Barrier Reef over a 6 year period. Journal of Fish Biology, vol. 67, no. 1, pp. 83-101. http:// dx.doi.org/10.1111/j.0022-1112.2005.00714.x.

HUNTER, J.R. and MACEWICZ, B., 1985a. Sexual maturity, batch fecundity, spawning frequency and temporal pattern in the northern anchovy, Engraulis mordax, during the 1979 spawning season. California Cooperative Oceanic Fisheries Investigations Reports, vol. 21, pp. 139-149.

HUNTER, J.R. and MACEWICZ, B., 1985b. Measurement of spawning frequency in multiple spawning fishes. In: R. LASKER, ed. An egg production method for estimating spawning biomass of pelagic fish: application to the Northern Anchovy, Engraulis mordax. Silver Spring: National Marine Fisheries Service, vol. 36, pp. 79-93. NOAA Technical Report.

HUNTER, J.R. and MACEWICZ, B., 1985c. Rates of atresia in the ovary of captive and wild northern anchovy, Engraulis mordax. Fish Bulletin, vol. 83, pp. 119-136.

HUNTER, J.R., LO, N C.H. and LEONG, R.J.H., 1985, Batch fecundity in multiple spawning fishes. In: R. LASKER, ed. An egg production method for estimating spawning biomass of pelagic fish: application to the Northern Anchovy, Engraulis mordax. Silver Spring: National Marine Fisheries Service, vol. 36, pp. 67-77. NOAA Technical Report.

KAUNDA-ARARA, B. and NTIBA, M.J., 1997. The reproductive biology of Lutjanus fulviflamma (Forsskal, 1775) in Kenyan inshore marine waters. Hydrobiologia, vol. 353, no. 1/3, pp. 153-160. http://dx.doi.org/10.1023/A:1003011013136.

KOJIS, B.L. and QUINN, N.J., 2011, Validation of a Spawning Aggregation of Mutton Snapper and Characterization of the Benthic Habitats and Fish in the Mutton Snapper Seasonal Closed Area, St. Croix, U.S. Virgin Islands. Puerto Rico: Caribbean Fisheries Management Council. 221 p. NOAA Coral Reef Grant Program. Projects to improve or amend Coral ReefFMPS NA08NMF4410463.

KRITZER, J.P., 2004. Sex-specific growth and mortality, spawning season, and female maturation of the stripey bass (Lutjanus carponotatus) on the Great Barrier Reef. Fish Bulletin, vol. 102, pp. 94-107.

LOWERRE-BARBIERI, S.K., GANIAS, K., SABORIDO-REY, F., MURUA, H. and HUNTER, J.R., 2011. Reproductive timing in marine fishes: variability, temporal scales, and methods. 2011. Marine and Coastal Fisheries, vol. 3, no. 1, pp. 71-91. http:// dx.doi.org/10.1080/19425120.2011.556932.

MACKIE, M. and LEWIS, P., 2001, Assessment of gonad staging systems and other methods used in the study of the reproductive biology of narrow-barred Spanish mackerel, Scomberomorus commerson. North Beach: Department of Fisheries, Government of Western Australia. Fisheries Research Report, no. 136

MARQUES, S. and FERREIRA, B.P., 2011. Sexual development and reproductive pattern of the Mutton hamlet, Alphestes afer (Teleostei: Epinephelidae): a dyandric, hermaphroditic reef fish. Neotropical Ichthyology, vol. 9, no. 3, pp. 547-558. http://dx.doi. org/10.1590/S1679-62252011005000026.

MOURA, R.L. and LINDEMAN, K.C., 2007. A new species of snapper (Perciformes: Lutjanidae) from Brazil, with comments on distribution of Lutjanus griseus e L. apodus. Zootaxa, vol. 1422, pp. 31-43.

MURUA, H., KRAUS, G., SABORIDO-REY, F., WITTHAMES, P.R., THORSEN, A. and JUNQUERA, S., 2003. Procedures to estimate fecundity of wild collected marine fish in relation to fish reproductive strategy. Journal of Northwest Atlantic Fishery Science, vol. 33, pp. 33-54. http://dx.doi.org/10.2960/J.v33.a3.

NELSON, J.S., 1984. Fishes of the world. 2nd ed. New York: John Wiley \& Sons. 523 p.

NEWMAN, S.J., WILLIAMS, D.M. and RUSS, G.R., 1996. Age validation, growth and mortality rates of the tropical snappers (Pisces: Lutjanidae) Lutjanus adetii (Castelnau, 1873) and L. quinquelineatus (Bloch, 1790) from the central Great Barrier Reef, Australia. Marine \& Freshwater Research, vol. 47, no. 4, pp. 575-584. http://dx.doi.org/10.1071/MF9960575. 
PALAZÓN-FERNÁNDEZ, J.L., 2007. Reproduction of the white grunt, Haemulon plumieri (Lacépede, 1802) (Pisces: Haemulidae) from Margarita Island, Venezuela. Scientia Marina, vol. 71, no. 3, pp. 429-440. http://dx.doi.org/10.3989/scimar.2007.71n3429.

PETERSEN, C.W. and WARNER, R.R., 2002, The ecological context of reproductive behavior. In: P.F. SALE, ed. Coral reef fishes: dynamics and diversity in a complex ecosystem. California: Academic Press, pp. 103-118.

ROJAS, J.R., 1997. Fecundidad y épocas de reproducción del pargo mancha Lutjanus guttatus (Pises: Lutjanidae) en el Golfo de Nicoya, Costa Rica. Revista de Biologia Tropical, vol. 44/45, pp. 477-487.

RONG-QUEN, J., 2000. Resource limitation underlying reproductive strategies of coral reef fishes: a hypothesis. Zoological Studies, vol. 39 , no. 3 , pp. 266-274.

SADOVY, Y., 1996. Reproduction of reef fishery species. In: N.V.C. POLUNIN and C.M. ROBERTS, eds. Reef fisheries. London: Chapman \& Hall, pp. 15-59.

SHINOZAKI-MENDES, R.A., SANTANDER-NETO, J., SILVA, J.R.F. and HAZIN, F.H.V., 2013a. Gonad maturation of Haemulon plumieri (Teleostei: Haemulidae) in Ceará state, Northeastern Brazil. Brazilian Journal of Biology $=$ Revista Brasileira de Biologia, vol. 73, no. 2, pp. 383-390. http://dx.doi.org/10.1590/ S1519-69842013000200019. PMid:23917566.

SHINOZAKI-MENDES, R.A., SANTANDER-NETO, J., SILVA, J.R.F. and HAZIN, F.H.V., 2013b. Reproductive biology of Haemulon plumieri (Teleostei: Haemulidae) in Ceará state, Northeastern Brazil. Brazilian Journal of Biology $=$ Revista Brasileira de Biologia, vol. 73, no. 2, pp. 391-396. http://dx.doi.org/10.1590/ S1519-69842013000200020. PMid:23917567.

SUZUKI, K. and HIOKI, S., 1979. Spawning behavior, eggs and larvae of the lutjanid fish, Lutjanus kasmira in aquarium. Japanese Journal of Ichthyology, vol. 26, pp. 161-166.

TEIXEIRA, S., DUARTE, Y.F. and FERREIRA, B.P., 2010. Reproduction of the fish Lutjanus analis (mutton snapper; Perciformes: Lutjanidae) from Northeastern Brazil. Revista de Biologia Tropical, vol. 58, no. 3, pp. 791-800. http://dx.doi. org/10.15517/rbt.v58i2.5246. PMid:20737838.

TROTT, T.M., 2006. Preliminary analyses of age, growth, and reproduction of Coney (Cephalopholis fulva) at Bermuda. Proceedings of the Gulf and Caribbean Fisheries Institute, vol. 57, pp. 385-400.

WALLACE, R.A. and SELMAN, K., 1981. Cellular and dynamic aspects of oocyte growth in teleost. American Zoologist, vol. 44, pp. 133-159.

WEST, G., 1990. Methods of assessing ovarian development in fishes: a review. Australian Journal of Marine and Freshwater Research, vol. 41, no. 2, pp. 199-222. http://dx.doi.org/10.1071/ MF9900199.

ZAR, J.H., 1999, Biostatistical analysis. New Jersey: Prentice Hall. 663 p. 